\title{
Prospects and Problems of Indigenous Sheep Production in South-Western Coastal Regions of Bangladesh
}

\author{
S.S. Islam ${ }^{1}$, M.S. Hasan ${ }^{1}$, N. Ghosh ${ }^{1}$, M.S. Islam ${ }^{1}$ and M.M. Islam ${ }^{\text {* }}$
}

Date Received: $3^{\text {rd }}$ June 2020 / Date Accepted: $7^{\text {th }}$ September 2020

\begin{abstract}
Purpose: The study was conducted to observe the prospects and problems of sheep farming in south-western coastal regions of Bangladesh.

Research Method: The study was based on survey data collection. An interview schedule was prepared to collect data from the sheep farmers keeping the objectives in mind. Data were collected from 90 sheep farmers who were chosen randomly from three different upazilas (sub-districts) covering 30 from each. The duration of data collection was from June to September, 2019.
\end{abstract}

Findings : The socio-economic status of the sheep farmers was studied. The majority (61.1\%) of the sheep farmers was middle aged group (31-50 years) and more than half (52.2\%) of the sheep farmers were found illiterate. The average number of sheep per household was 6.5 3.69. The average age at puberty, age at first lambing, lambing interval, litter size, lactation length and gestation length of coastal sheep were $224.78 \pm 10.68$ days, $388.39 \pm 13.13$ days, $214.22 \pm 9.12$ days, $2.84 \pm 0.73,104.22 \pm 13.74$ days and $149.44 \pm 5.27$ days, respectively. Majority (94.44\%) of the sheep farmers stated that their income was increased after adopting sheep farming and about 5.6\% of the sheep farmers did not sell their sheep yet. More than half (56.7\%) of the sheep farmers described sheep farming as high prospect and $43.3 \%$ cases it was described as moderate prospect. About $80 \%$ of the sheep farmers stated that their problem facing score ranged between 20 and 39 i.e., their problem facing intensity was moderately severe during sheep farming.

Originality/Value : The results of the study revealed that instead of few problems faced by the farmers, the prospects of sheep farming in south-western coastal region was high as it requires less space and investment and it also increased the income of the farmers.

Keywords: Coastal sheep, Income generation, Poverty reduction, Production performance, Reproductive performance

\section{INTRODUCTION}

In Bangladesh, livestock is one of the most important sub-sectors of agriculture which plays a vital role in promoting national economy of the country (Sharma et al., 2014). About 80 to $85 \%$ of the households keep livestock in the rural areas and most of them are landless, marginal and small farmers (Hossain et al., 2016). Livestock may be considered as "Cash income" to rural farmers that is instantly available for sale or exchange (Hossen et al., 2008). Most of the people of Bangladesh are poor and as a result they are victims of malnutrition. Livestock sector covers about $1.66 \%$ of national GDP and its annual growth rate is $3.21 \%$ (DLS, 2015). Among all small ruminants, the popularity of sheep farming is increasing day by day in our country. As sheep farming does not need much space, the landless and marginal farmers are rearing sheep for additional income generation. Sheep do not require a lot of feed and the most important thing is they do not have a particular

\footnotetext{
Agrotechnology Discipline, Khulna University, Khulna-9208, Bangladesh

matiul_rubel@yahoo.com
}

(D) http://orcid.org/0000-0001-7892-4666 
feed habit. They can eat grass and leaves from pasture themselves. On the basis of traditional feeding nature, sheep are reared on fallow lands, roadsides and the sides of canals (Sultana et al., 2010). So, there is no need of much labor for their maintenance. Much skill is also not needed so that illiterate men and women and children can take care of a sheep farm.

Bangladesh suffers from shortage of livestock products. Sheep production can be the expectancy of excess animal protein supply for these people. About 3.401 million sheep heads are distributed throughout the country (DLS, 2017). A few crossbreeds are reared but most of the sheep are indigenous (Bhuiyan, 2006). The scope of sheep farming is high in the context of Bangladesh. As it is a subtropical country, the weather is suitable for sheep production. After all, sheep farming may keep a huge contribution in the economy of Bangladesh by generating income and creating job opportunities. Farmers can get wool as a byproduct from sheep which has a great demand in world market and it may allow them to earn foreign currency. The annual total wool production of coastal sheep was reported about $853.9 \mathrm{~g}$ per sheep (Hassan and Talukdar, 2011). Although sheep farming has a huge economic potential in the coastal areas of Bangladesh, it is not problem free. Besides, the prospect of sheep farming is yet to be assessed scientifically for determining worthiness in reducing poverty of the local people. Scientific investigations are hardly available in this regard, particularly on sheep farming. Therefore, the present study was undertaken to study the production and reproductive performances of indigenous sheep and to observe the prospects and problems of sheep farming in the south-western coastal regions in Bangladesh.

\section{MATERIALS AND METHODS}

\section{Location and sampling of the study}

The study was conducted in purposively selected three upazilas (sub-districts) of south-western coastal regions of Bangladesh. These were Dacope upazila of Khulna, Mongla upazila of Bagrehat and Shymnagar upazila of Satkhira districts. Thirty sheep farmers who were ready or available to provide information were selected randomly (first met first interviewed) from each upazila and the total number of farmers interviewed was ninety.

\section{Preparation of interview schedule and data collection}

An interview schedule was prepared very carefully to collect relevant and useful information from the sheep farmers keeping the objectives of the study in mind. Both open and close ended questions were contained in it and all the questions were in direct and simple form. The interview schedule was pretested with 10 farmers after preparing it. All necessary corrections as well as modifications were done after the pre-test. The data for this study were collected by face-toface interviewing of the sheep farmers according to the interview schedule during the period from June to September 2019. As the sheep farmers did not have any written document, they were replying from their memory. The data sheets were checked and verified after every interview to be sure that the responses of the sheep farmers were recorded properly.

\section{The issues addressed in the study}

The issues which were addressed in the study included socio-economic information of the sheep farmers (age, education, family size, occupation, farming experience, farm size, income, etc.), social information (crop and sheep farming experience, training exposure, media contact, etc.), psychological (knowledge on sheep rearing, attitude towards sheep farming), farm management related information (farming system, types of feed supplied to the sheep, treatment and vaccination, etc.) and sheep related information (number of sheep per household, production and reproductive performances of sheep, etc.). Focus issues covered prospects of sheep farming (income generation by sheep farming, relative advantages, poverty reduction, etc.) and problems faced [breed related problems (i.e., unavailability of improved breed other than 
the local ones), feed and fodder related problems, health related problems, etc.].

\section{Measurement of the issues}

Measurement of the different independent issues, such as socioeconomic information of the sheep farmers, socio-psychological, farm management related information and sheep related information were measured following standard procedures as used by Islam et al. (2019) and Zinea et al. (2019).

\section{Measurement of problem faced during sheep rearing: The sheep farmers were asked about the problems faced in sheep rearing. A number of 19 problems were incorporated in the questionnaire. The problems were categorized into highly severe, moderately severe, less severe, not at all a problem and scores of 3, 2, 1 and 0 were assigned to the scale respectively. The number of problems from different aspects was 18 (Table 20) and thus the problem facing score could range between 0 and 54 . Based on problem scores obtained by the individual farmer, the sheep farmers were classified (following approximately equal three divisions of the possible score range) into three categories: less severe ( $<20$ score), moderately severe (20-39 score) and highly severe (>39 score).}

Besides this, the 18 problems were ranked based on total score obtained by 90 sheep farmers against the particular problem. The score could be ranged from 0-270 where " 0 " indicates no problem and "270" indicates a highly severe problem.

Measurement of prospect of sheep farming: The sheep farmers were asked some questions which were related to relative advantages, poverty reduction, employment and income generation. Total 17 prospects were decided and the prospect score for individual farmer could range from 0 to 51 . Based on prospect scores obtained by the individual farmers, the sheep farmers were classified (following approximately equal three divisions of the possible score range) into three categories: less prospect ( $<18$ score), moderate prospect (18-33 score) and high prospect ( $>33)$.

Besides this, the 17 prospects were ranked based on a total score obtained by 90 sheep farmers against the particular prospect. The score could be ranged from 0-270 where " 0 " indicates no prospect and " 270 " indicates high prospect.

\section{Data tabulation and analysis}

After completing collection, all the data were compiled, coded and then tabulated for the processing. Local units were converted into standard units. Different statistical methods were used like number, mean, SD, minimum, maximum and percentage to explain the variables. To analyze the data, the SPSS statistics 16.0 program was used.

\section{RESULTS AND DISCUSSION}

\section{Socio-economic information of the sheep farmers}

Data of the Table 01 shows that the majority $(61.1 \%)$ of the sheep farmers was middle aged followed by old aged $(25.6 \%)$ and young aged $(13.3 \%)$. The average age (years) of the sheep farmers in the studied area was 44.16 \pm 11.97 ; i.e., the farmers' measurement of dispersion was not so high and they might contribute for a long time through their expertise in sheep farming. The results of this study were inconsistent with that of Rahman et al. (2012) where they reported that $45.3 \%$ of farmers were in middle aged category, $16.0 \%$ and $38.7 \%$ farmers were in young and old aged category, respectively. Our present findings are almost similar with Begum et al. (2007) and Ahamed et al. (2010). It was expected that middle aged farmers were more active, energetic and enthusiastic in performing sheep rearing activities. Majority $(52.2 \%)$ of the sheep farmers were illiterate followed by secondary $(25.6 \%)$, primary $(18.9 \%)$, higher secondary $(2.2 \%)$ and graduate or above $(1.1 \%)$ level of education. The average schooling year was $3.31 \pm 4.06$. This result advocates that these 
farmers might not be competent enough to adopt other "difficult to understand and apply" type of income generation activities due to their very low educational qualifications. The results of this study were inconsistent with that of Begum et al. (2007), where they reported that $20 \%$ farmers were illiterate, $40 \%, 30 \%$ and $10.0 \%$ farmers had primary, secondary and above secondary level of education, respectively. It was assumed that educated people could perform better sheep production measure. About $45.0 \%$ of the sheep farmers had small sized family followed by medium $(43.0 \%)$ and large sized $(12.0 \%)$ family (Table 01). The average number of family member was $5.08(\approx 5)$ with standard deviation 2.23. Whereas Kamal et al. (2012) observed that almost half $(49.3 \%)$ of the farmers had a medium size family followed by a small size (34\%) and large size (16.7\%) family. The study also indicates that majority ( $63.3 \%)$ of the farmers had marginal farm size followed by small (23.3\%), landless
$(12 \%)$ and medium (1.1\%) farm size (Table 01). The sheep farmers had an average 0.123 ha of land. The results of this study were inconsistent with Hossain (2013) where he reported that 23\% farmers were marginal, $40 \%$ farmers had small, $30 \%$ farmers had a medium and $7 \%$ farmers had a large land size. The findings also indicate that majority $(74.4 \%)$ of the sheep farmers belonged to low annual income group followed by medium $(16.7 \%)$ and high $(8.9 \%)$ income group (Table $01)$. The average income of the sheep farmers was $1,01,565 \pm 53,606.64 \mathrm{BDT} /$ household/year (i.e., $1,197.90 \pm 632,26$ USD; $1 \quad$ USD $=84.81$ BDT) $(\mathrm{BDT}=$ Bangladeshi Taka; USD=United States Dollar). The findings of the study was almost similar with that of Kamal et al. (2012) where they observed that majority (64\%) of the respondent belonged to the low income group followed by the medium (26\%) and high $(9.3 \%)$ income group.

Table 01: Socioeconomic factors of the sheep farmers.

\begin{tabular}{|c|c|c|c|c|c|c|}
\hline Characters & Categories & Score & Frequency & Percent & $\begin{array}{c}\text { Cumulative } \\
\text { Percent }\end{array}$ & Mean \pm SD \\
\hline \multirow{4}{*}{ Age (Years) } & Young age & $\leq 30$ & 12 & 13.3 & 13.3 & \multirow{4}{*}{$44.16 \pm 11.97$} \\
\hline & Medium age & $31-50$ & 55 & 61.1 & 74.4 & \\
\hline & Old age & $>50$ & 23 & 25.6 & 100.0 & \\
\hline & Total & & 90 & 100.0 & & \\
\hline \multirow{6}{*}{$\begin{array}{l}\text { Education } \\
\text { level } \\
\text { (Year of } \\
\text { schooling) }\end{array}$} & Illiterate & 0 & 47 & 52.2 & 52.2 & \multirow{6}{*}{$3.31 \pm 4.06$} \\
\hline & Primary & $1-5$ & 17 & 18.9 & 71.1 & \\
\hline & Secondary & $6-10$ & 23 & 25.6 & 96.7 & \\
\hline & Higher second. & $11-12$ & 2 & 2.2 & 98.9 & \\
\hline & $\geq$ Graduate & $>12$ & 1 & 1.1 & 100.0 & \\
\hline & Total & & 90 & 100.0 & & \\
\hline \multirow{4}{*}{$\begin{array}{l}\text { Family size } \\
\text { (No.) }\end{array}$} & Small & $1-4$ & 40 & 44.4 & 44.4 & \multirow{4}{*}{$5.08 \pm 2.22$} \\
\hline & Medium & $5-7$ & 39 & 43.3 & 87.8 & \\
\hline & Large & $>7$ & 11 & 12.2 & 100.0 & \\
\hline & Total & & 90 & 100.0 & & \\
\hline \multirow{5}{*}{$\begin{array}{l}\text { Farm size } \\
\text { (ha/ } \\
\text { household) }\end{array}$} & Landless & $<0.02$ & 11 & 12.2 & 12.2 & \multirow{5}{*}{$0.12 \pm 0.19$} \\
\hline & Marginal & $0.02-0.2$ & 57 & 63.3 & 75.6 & \\
\hline & Small & $0.21-1.0$ & 21 & 23.3 & 98.9 & \\
\hline & Medium & $1.01-3.0$ & 1 & 1.1 & 100.0 & \\
\hline & Total & & 90 & 100.0 & & \\
\hline \multirow{4}{*}{$\begin{array}{l}\text { Annual } \\
\text { income } \\
\text { (BDT/ } \\
\text { household) }\end{array}$} & Low Income & $<100,000$ & 67 & 74.4 & 74.4 & \multirow{4}{*}{$101,565 \pm 53,606.64$} \\
\hline & Medium income & $\begin{array}{c}100,000 \\
-150,000\end{array}$ & 15 & 16.7 & 91.1 & \\
\hline & High Income & $>150,000$ & 8 & 8.9 & 100.0 & \\
\hline & Total & & 90 & 100.0 & & \\
\hline
\end{tabular}




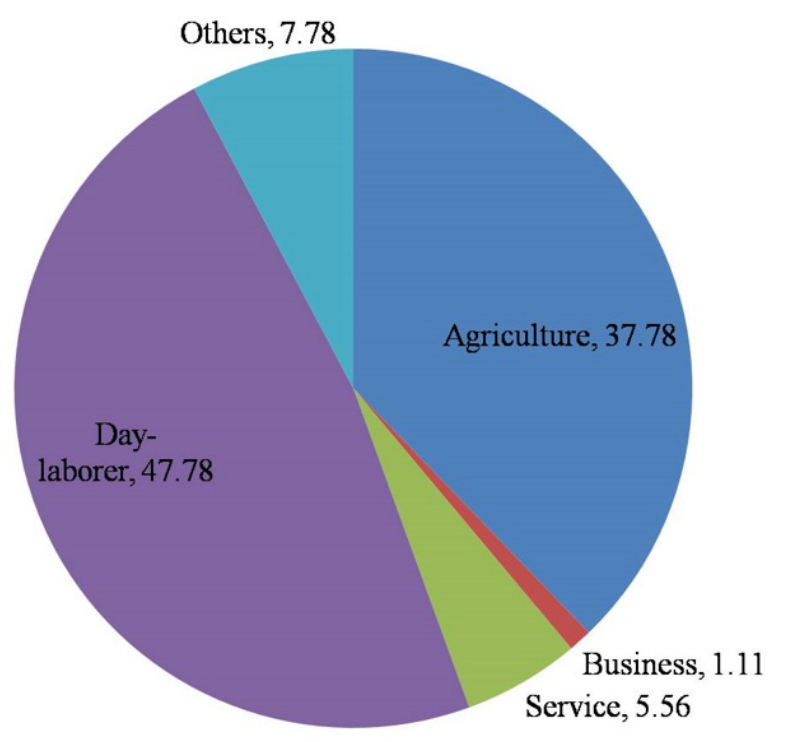

\section{Figure 01: Farmers' category according to their occupation}

Figure 01 represents that the occupation of $47.78 \%$ sheep farmers was day laborer followed by agriculture $(37.78 \%)$, others $(7.78 \%)$, service (5.56) and the business (1.11\%). Kamal et al. (2012) found that the occupation of majority of the farmers $(61.3 \%)$ was agriculture followed by day laborer (18.7\%), businessman (13.3\%) and the lowest number of farmers $(6.7 \%)$ engaged in service.

\section{Socio-psychological information of the sheep farmers}

Data presented in Table 02 reveal that the average crop farming experience of the sheep farmers of Dacope upazilla was $16.93 \pm 13.03$ years followed by Mongla (16.57 \pm 10.53 years) and Shyamnagar upazilla (10.78 \pm 12.49 years). The average crop farming experience of the studied area was $14.76 \pm 12.26$ years. The findings also show that the average sheep farming experience of the farmers of Shyamnagar upazilla was $8.33 \pm 11.13$ years followed by the farmers of Mongla (7.17 \pm 4.09 years) and Dacope upazilla (6.17 \pm 3.15 years). The average sheep farming experience of the studied area was 7.22 \pm 7.06 years. The result of the study differed with that of Kamal et al. (2012) where they observed that the average crop farming experience of the respondents was around 20 years and average goat farming experience was around 11 years.

Table 02: Crop and sheep farming experience of the farmers at different locations.

\begin{tabular}{lcc}
\hline \multicolumn{1}{c}{ Location of the study } & $\begin{array}{c}\text { Experience of crop farming } \\
\text { (years) }\end{array}$ & $\begin{array}{c}\text { Experience of sheep farming } \\
\text { (years) }\end{array}$ \\
\hline Mongla (N=30) & $16.57 \pm 10.53$ & $7.17 \pm 4.09$ \\
Dacope (N=30) & $16.93 \pm 13.03$ & $6.17 \pm 3.15$ \\
Shyamnagar (N=30) & $10.78 \pm 12.49$ & $8.33 \pm 11.13$ \\
Overall (N=90) & $14.76 \pm 12.26$ & $7.22 \pm 7.06$ \\
F-value & 2.45 & 0.70 \\
Level of significance & $\mathrm{NS}$ & $\mathrm{NS}$ \\
\hline
\end{tabular}


The study shows that about $94.4 \%$ of the sheep farmers had no training on sheep farming (Table 03). However, $5.6 \%$ of the sheep farmers had low training (1 to 2 trainings) on sheep farming. Kamal et al. (2012) observed that majority of $(79.3 \%)$ respondent farmers had no training on sheep/goat farming followed by $16.7 \%$ low training, $3.3 \%$ medium training and $0.7 \%$ of the farmers had high training exposure on sheep/goat rearing.

Around $91.1 \%$ of the sheep farmers had low media contact followed by medium (8.9\%) extension media contact (Table 04).

\section{Knowledge and attitude of the sheep farmers}

The results revealed that $93.3 \%$ of the sheep farmers had reported that they have medium knowledge about sheep rearing followed by low $(5.6 \%)$ and high knowledge (1.1\%) (Table 05). Kamal et al. (2012) stated that $69.7 \%$ of the sheep farmers had medium knowledge followed by low $(20 \%)$ and high knowledge $(9.3 \%)$ on goat rearing.

Data of the Table 06 indicate that more than half $(53.3 \%)$ of the sheep farmers showed a high positive attitude towards sheep farming followed by the medium (43.3\%) and low (3.3\%) attitude.

Table 03: Distribution of the sheep farmers according to their training exposure.

\begin{tabular}{lcccc}
\hline \multicolumn{1}{c}{ Categories } & Score (No. of training) & Frequency & Percent & Cumulative Percent \\
\hline No Training & 0 & 85 & 94.4 & 94.4 \\
Low training & $1-2$ & 5 & 5.6 & 100.0 \\
Total & & 90 & 100.0 & \\
\hline
\end{tabular}

Table 04: Distribution of the sheep farmers according to their extension media contact.

\begin{tabular}{lccccc}
\hline \multicolumn{1}{c}{ Categories } & Score & Frequency & Percent & Cumulative Percent & Average \pm SD \\
\hline Low contact & $\leq 10$ & 82 & 91.1 & 91.1 & $8.00 \pm 1.914$ \\
Medium contact & $11-20$ & 8 & 8.9 & 100.0 & \\
Total & & 90 & 100.0 & & \\
\hline
\end{tabular}

Table 05: Distribution of the sheep farmers according to their sheep rearing knowledge.

\begin{tabular}{lccccc}
\hline \multicolumn{1}{c}{ Categories } & Score & Frequency & Percent & Cumulative Percent & Average \pm SD \\
\hline Low knowledge & $1-7$ & 5 & 5.6 & 5.6 & $9.40 \pm 1.44$ \\
Medium knowledge & $8-14$ & 84 & 93.3 & 98.9 & \\
High knowledge & $15-20$ & 1 & 1.1 & 100.0 & \\
Total & & 90 & 100.0 & & \\
\hline
\end{tabular}

Table 06: Distribution of the sheep farmers according to their attitude towards sheep farming.

\begin{tabular}{lccccc}
\hline Categories & Score & Frequency & Percent & Cumulative Percent & Average \pm SD \\
\hline Low & $\leq 23$ & 3 & 3.3 & 3.3 & $37.50 \pm 6.67$ \\
Medium & $24-37$ & 39 & 43.3 & 46.7 & \\
High & $38-50$ & 48 & 53.3 & 100 & \\
Total & & 90 & 100.0 & & \\
\hline
\end{tabular}




\section{Farm management}

The results revealed that $81.1 \%$ of the sheep farmers followed only a livestock farming system, followed by Crop + Livestock system $(16.7 \%)$, Livestock + Fish system $(1.1 \%)$ and Crop + Livestock + Fish farming system (1.1\%) (Table 07). Kamal et al. (2012) noticed that $59.3 \%$ farmer followed a crop + livestock farming system followed by crop + livestock + fish (35.3\%) and only $4.7 \%$ had a livestock farming system.

The results of the study showed that $97.8 \%$ of the sheep farmers fed leaves and grasses to their sheep and about $2.2 \%$ of the sheep farmers used concentrates as supplementary feed in addition to grass and leaves (Table 08). In another study $60 \%$ of the sheep fed roadside grass and only $33 \%$ sheep fed cultivated fodder and roadside grass during rainy season (Sarker et al., 2017).
For treatment of sick sheep, $87.8 \%$ of the farmers contacted a local doctor and 3.3\% contacted a veterinarian (Table 09). Rest of the sheep farmers $(8.9 \%)$ did not practice any treatment measures for their sick animals. Kamal et al. (2012) found that $73.3 \%$ of the farmers contacted a local doctor and $26.3 \%$ of the farmers contacted a veterinarian for the treatment of small ruminant diseases.

The results of the study showed that $90 \%$ of the farmers gave vaccines to their sheep and $10 \%$ of the sheep farmers did not vaccinate their sheep (Table 10). Begum et al. (2007) reported that $83.3 \%$ of the farmers used vaccination, $80 \%$ of the farmers took activities for de-worming. Another study stated that about $80 \%$ of the farmers regularly vaccinated their sheep, $87 \%$ of the farmers did not use antibiotics, hormones, and growth regulators for meat production and only $13 \%$ farmers used these for sheep production (Sarker et al., 2017).

Table 07: Distribution of sheep farmers according to their farming system.

\begin{tabular}{lccc}
\hline \multicolumn{1}{c}{ Components } & Frequency & Percent & Cumulative Percent \\
\hline Livestock & 73 & 81.1 & 81.1 \\
Crop + Livestock & 15 & 16.7 & 97.8 \\
Livestock + Fish & 1 & 1.1 & 98.9 \\
Crop + Livestock + Fish & 1 & 1.1 & 100.0 \\
Total & 90 & 100.0 & \\
\hline
\end{tabular}

Table 08: Distribution of sheep farmers according to the types of feed supplied.

\begin{tabular}{lccc}
\hline \multicolumn{1}{c}{ Types } & Frequency & Percent & Cumulative Percent \\
\hline Leaves + Grass & 88 & 97.8 & 97.8 \\
Leaves + Grass + Concentrate & 2 & 2.2 & 100.0 \\
Total & 90 & 100.0 & \\
\hline
\end{tabular}

Table 09: Treatment procedure of sick sheep in south-western coastal regions.

\begin{tabular}{lccc}
\hline \multicolumn{1}{c}{ Categories } & Frequency & Percent & Cumulative Percent \\
\hline Local doctor & 79 & 87.8 & 87.8 \\
Veterinarian & 3 & 3.3 & 91.1 \\
No treatment & 8 & 8.9 & 100.0 \\
Total & 90 & 100.0 & \\
\hline
\end{tabular}

Table 10: Vaccination pattern of sheep in south-western coastal regions.

\begin{tabular}{lccc}
\hline \multicolumn{1}{c}{ Categories } & Frequency & Percent & Cumulative Percent \\
\hline Vaccinated & 81 & 90.0 & 90.0 \\
Not vaccinated & 9 & 10.0 & 100.0 \\
Total & 90 & 100.0 & \\
\hline
\end{tabular}




\section{Statistics of sheep production}

Data contained in the Table 11 indicate that the average total number of sheep per household in Mongla upazilla was $7.17 \pm 3.15$ where number of male, female and lamb were $1.80 \pm 1.19$, $3.03 \pm 1.40$ and $2.33 \pm 1.65$, respectively. In Dacope upazilla the average number of sheep was $6.5 \pm 1.98$ where average numbers of male, female and lambs were $1.23 \pm 1.31,2.77 \pm 1.01$ and $2.53 \pm 1.36$ per household, respectively. In Shyamnagar upazilla the average number of sheep was $5.83 \pm 5.20$ where average numbers of male, female and lambs were $0.83 \pm 1.90,3.0 \pm 2.30$ and $2.07 \pm 2.02$ per household, respectively. Among three different locations of the study, the highest average number of sheep and male sheep was found in Mongla upazilla.

Age at puberty of sheep did not differ significantly among different upazilas (Table 12). Age at puberty at Mongla, Dacope and Shyamnagar was $226.17 \pm 9.62,223.17 \pm 11.10$ and $225.00 \pm 11.37$ days, respectively. On the basis of nutrition, breed and date of birth, the age of puberty ranges from 5 to 20 months for female sheep (Ensminger, 2002). In Rajasthan Rambouillet crossbreds come to puberty at 615 days old (Kishore et al., 1982). Age at first lambing (days) did not differ significantly among the locations of the study but higher in Dacope $(394 \pm 15.22)$ followed by Shyamnagar $(387.83 \pm 10.31)$ and Mongla (383.33 \pm 11.47$)$. Lambing interval (days) of sheep at Mongla, Dacope and Shyamnagar was $212.33 \pm 7.63,215.67 \pm 8.28$ and $214.67 \pm 11.6$, respectively where the mean difference was non-significant $(\mathrm{p}>0.05)$. Husain and Amin (2003) reported that lambing interval of native sheep was 253 days which is higher than the findings of present study. Nimbkar et al. (2002) found the average lambing interval was 264 \pm 81 days in Deccani sheep in India which is also higher than the present findings. Gestation length did not differ significantly amongthe three areas. Gestation length at Mongla, Dacope and Shyamnagar was $148.17 \pm 3.59, \quad 149.17 \pm 5.58$ and $151.00 \pm 6.07$ days, respectively (Table 12). Husain and Amin (2003) reported that the gestation period of native sheep was 149.0 days which was similar to the present findings. Litter size did not differ significantly among the three areas but was numerically higher in Shyamnagar (2.97) followed by Mongla (2.80) and Dacope (2.77). Nimbkar et al. (2002) found that the average litter size of Garole $x$ Deccani sheep was 1.6 and Banerjee (2008) reported litter size of 1.9 in native Bengal Garole which was lesser than that of present findings. Large litter size and short lambing interval of indigenous sheep of south-western coastal regions of Bangladesh indicate that this sheep is more prolific in nature. Indigenous sheep of south-western coastal regions were low milk producers. Therefore, farmers in all areas under study reported that they did not get milk from their sheep. The lambs usually suck the udder to fulfill their requirements. Lactation length did not differ significantly among the three areas. Lactation length of indigenous sheep at Mongla, Dacope and Shyamnagar was $104.00 \pm 11.77,103.67 \pm 10.08$ and $105.00 \pm 18.38$ days, respectively.

Table 11: Total number of sheep per household according to three different locations of the study.

\begin{tabular}{lcccc}
\hline \multicolumn{1}{c}{ Location of study } & $\begin{array}{c}\text { Total number of } \\
\text { sheep }\end{array}$ & $\begin{array}{c}\text { Number of male } \\
\text { sheep }\end{array}$ & $\begin{array}{c}\text { Number of } \\
\text { female sheep }\end{array}$ & Number of lamb \\
\hline Mongla $(\mathrm{N}=30)$ & $7.17 \pm 3.15$ & $1.80 \pm 1.19$ & $3.03 \pm 1.40$ & $2.33 \pm 1.65$ \\
Dacope $(\mathrm{N}=30)$ & $6.50 \pm 1.98$ & $1.23 \pm 1.31$ & $2.77 \pm 1.01$ & $2.53 \pm 1.36$ \\
Shyamnagar $(\mathrm{N}=30)$ & $5.83 \pm 5.20$ & $0.83 \pm 1.90$ & $3.00 \pm 2.30$ & $2.07 \pm 2.02$ \\
Overall $(\mathrm{N}=90)$ & $6.50 \pm 3.69$ & $1.29 \pm 1.53$ & $2.93 \pm 1.65$ & $2.31 \pm 1.69$ \\
F-value & 0.98 & 3.17 & 0.23 & 0.57 \\
Level of significance & $\mathrm{NS}$ & $*$ & $\mathrm{NS}$ & $\mathrm{NS}$ \\
\hline
\end{tabular}

NS=Non-significant $;{ }^{*} p<0.05$ 
Table 12: Production and reproductive performances of sheep in three different locations.

\begin{tabular}{lcccccc}
\hline \multicolumn{1}{c}{ Location of study } & $\begin{array}{c}\text { Age at } \\
\text { puberty (days) }\end{array}$ & $\begin{array}{c}\text { Age at first } \\
\text { lambing } \\
\text { (days) }\end{array}$ & $\begin{array}{c}\text { Lambing } \\
\text { interval (days) }\end{array}$ & $\begin{array}{c}\text { Litter size } \\
\text { (no.) }\end{array}$ & $\begin{array}{c}\text { Lactation } \\
\text { length (days) }\end{array}$ & $\begin{array}{c}\text { Gestation } \\
\text { length (days) }\end{array}$ \\
\hline Mongla (N=30) & $226.17 \pm 9.62$ & $383.33 \pm 11.47$ & $212.33 \pm 7.63$ & $2.80 \pm 0.71$ & $104.00 \pm 11.77$ & $148.17 \pm 3.59$ \\
Dacope (N=30) & $223.17 \pm 11.10$ & $394.00 \pm 15.22$ & $215.67 \pm 8.28$ & $2.77 \pm 0.68$ & $103.67 \pm 10.08$ & $149.17 \pm 5.58$ \\
Shyamnagar (N=30) & $225.00 \pm 11.37$ & $387.83 \pm 10.31$ & $214.67 \pm 11.60$ & $2.97 \pm 0.81$ & $105.00 \pm 18.38$ & $151.00 \pm 6.07$ \\
Overall (N=90) & $224.78 \pm 10.68$ & $388.39 \pm 13.13$ & $214.22 \pm 9.12$ & $2.84 \pm 0.73$ & $104.22 \pm 13.74$ & $149.44 \pm 5.27$ \\
F-value & 0.60 & 5.50 & 1.06 & 0.64 & 0.08 & 2.30 \\
Level of significance & $\mathrm{NS}$ & $* *$ & $\mathrm{NS}$ & $\mathrm{NS}$ & $\mathrm{NS}$ & $\mathrm{NS}$ \\
\hline
\end{tabular}

$N S=$ Non-significant $* * p<0.01$

\section{Prospects of sheep farming}

About $94.44 \%$ of the respondents stated that their income was increased after sheep farming and about $5.6 \%$ of the sheep farmers did not sale their sheep yet (Table 13). The average annual income from sheep was 7,932.22 $\pm 4,327.51$ BDT per household (i.e., 93.56 \pm 51.04 USD).

More than half $(56.7 \%)$ of the sheep farmers described sheep farming as high prospective and in $43.3 \%$ cases it was described as moderately prospective (Table 14). Nobody stated indigenous sheep farming as low or no prospect in southwestern coastal regions of Bangladesh. The sheep farmers of the study area do not have that much educational qualifications and other psychomotor competence to perform other income generating activities as a prospect for their socio-economic development. However, they have experience and expertise for sheep farming, and as per their perception sheep farming is of moderate to high prospect for improvement of their socioeconomic status.

It was found that the requirement of space, investment and cost of housing was lower than large animal farming. Other advantages of sheep farming described by the farmers are ranked according to their merits [Table 15(1)].

Different aspects of poverty reduction by sheep farming are ranked in Table 15 (2).

Table 13: Distribution of sheep farmers on the basis of income generation from sheep farming.

\begin{tabular}{lcccc}
\hline \multicolumn{1}{c}{ Farmer's statement } & Frequency & Percent & $\begin{array}{c}\text { Cumulative } \\
\text { Percent }\end{array}$ & $\begin{array}{c}\text { Average } \pm \text { SD } \\
\text { (BDT/household/year) }\end{array}$ \\
\hline Increased income & 85 & 94.4 & 94.4 & $7,932.22 \pm 4,327.51$ \\
Not sold their sheep yet & 5 & 5.6 & 100.0 & \\
Total & 90 & 100.0 & & \\
\hline
\end{tabular}

Table 14: Prospect of sheep farming in south-western coastal regions.

\begin{tabular}{lccccc}
\hline \multicolumn{1}{c}{ Categories } & Score & Frequency & Percent & Cumulative Percent & Average \pm SD \\
\hline Low prospect & $<18$ & 00 & 00 & 00 & $35.82 \pm 4.35$ \\
Moderate prospect & $18-33$ & 39 & 43.3 & 43.3 & \\
High prospect & $>33$ & 51 & 56.7 & 100.0 & \\
Total & & 90 & 100.0 & & \\
\hline
\end{tabular}


Table 15: Rank order of prospect in sheep farming.

\section{1) Relative advantages}

\begin{tabular}{clccc}
\hline S1. No. & \multicolumn{1}{c}{ Statement } & Score & Percentage & Ranking \\
\hline 1. & Space requirement for sheep farming than other farming & 267 & 98.88 & $1^{\text {st }}$ \\
2. & Treatment cost & 213 & 78.88 & $7^{\text {th }}$ \\
3. & Mortality of sheep than other animal & 210 & 77.77 & $8^{\text {th }}$ \\
4. & Prolificacy of sheep than other animal & 244 & 90.37 & $6^{\text {th }}$ \\
5. & Investment in sheep farming than other farming & 264 & 97.77 & $2^{\text {nd }}$ \\
6. & Feed requirement than other farming & 250 & 92.59 & $4^{\text {th }}$ \\
7. & Cost of housing for sheep & 252 & 93.33 & $3^{\text {rd }}$ \\
8. & Labor requirement & 250 & 92.59 & $4^{\text {th }}$ \\
9. & Disease susceptibility & 177 & 65.55 & $9^{\text {th }}$ \\
10. & Need of skilled person & 252 & 93.33 & $3^{\text {rd }}$ \\
11. & Need of especial training & 249 & 92.22 & $5^{\text {th }}$ \\
\hline
\end{tabular}

2)

Poverty reduction

\begin{tabular}{clccc}
\hline S1. No. & Statement & Score & Percentage & Ranking \\
\hline 1. & How was your economic condition before sheep farming? & 61 & 22.59 & $6^{\text {th }}$ \\
2. & How is your economic condition after sheep farming? & 112 & 41.48 & $1^{\text {st }}$ \\
3. $\quad \begin{array}{l}\text { How does sheep farming help to change the infrastructure of } \\
\quad \text { your house? }\end{array}$ & 97 & 35.92 & $5^{\text {th }}$ \\
4. $\quad \begin{array}{l}\text { How does sheep farming contribute to the education of your } \\
\text { children? }\end{array}$ & 111 & 41.11 & $2^{\text {nd }}$ \\
5. $\quad$ How does sheep farming contribute to your clothing? & 108 & 40 & $4^{\text {th }}$ \\
6. $\quad \begin{array}{l}\text { How does sheep farming helps to get proper medical treat- } \\
\text { ment of your family members? }\end{array}$ & 109 & 40.37 & $3^{\text {rd }}$ \\
\hline
\end{tabular}

\section{Problems of sheep farming}

On the basis of the opinions provided by the respondents on a 4-point severity scale as per their perceptions against 18 problems the severity intensity of the faced problems was measured. The problems which were frequently faced by the farmers in the coastal areas were termed as the severe problems on the basis of magnitude of appearance and frequency of occurrence. Thus the severe problems could also be termed as the common problems. The findings stated that $80 \%$ of the sheep farmers faced moderately severe problems and only $20 \%$ faced highly severe problems (Table 16). Sarker et al. (2017) stated that the major problems of organic sheep production were the lack of technical knowledge, training facilities, high price of vitamins, minerals and supplementations. Hossain et al. (1996) found that high feed cost and shortage of animal feed were the greatest problems of the farmers for raising sheep.

The most severe problem for sheep rearing faced by the sheep farmers was the lack of facility of a veterinary surgeon (Table 17). Some other problems were found like high price of vaccine and medicine, lack of artificial insemination facilities, lack of capital and loan facilities and lack of training facilities. 
Table 16: Level of occurrence and severity of problems faced by sheep farmers.

\begin{tabular}{lccccc}
\hline \multicolumn{1}{c}{ Categories } & Score & Frequency & Percent & $\begin{array}{c}\text { Cumulative } \\
\text { Percent }\end{array}$ & Average \pm SD \\
\hline Less severe & $<20$ & 00 & 00 & 00 & $36.78 \pm 3.44$ \\
Moderately severe & $20-39$ & 72 & 80.0 & 80.0 & \\
Highly severe & $>39$ & 18 & 20.0 & 100.0 & \\
Total & & 90 & 100.0 & & \\
\hline
\end{tabular}

Table17: Rank order of the problems faced by the sheep farmers in sheep rearing.

\begin{tabular}{clccc}
\hline S1. No. & \multicolumn{1}{c}{ Types of problems } & Score & Percentage (\%) & Ranking \\
\hline A & Breed related problems & & & \\
1. & High price of good breed & 210 & 77.77 & $7^{\text {th }}$ \\
2. & Scarcity of quality breed in time & 194 & 71.85 & $9^{\text {th }}$ \\
3. & Scarcity of breeding rams & 120 & 44.44 & $16^{\text {th }}$ \\
\hline B & Feeds \& fodder related problems & & & \\
4. & High price of feeds and fodder & 186 & 68.88 & $12^{\text {th }}$ \\
5. & Unavailability of quality feeds and fodder & 192 & 71.11 & $10^{\text {th }}$ \\
6. & Lack of knowledge of fodder production & 179 & 66.29 & $13^{\text {th }}$ \\
7. & Scarcity of grazing land & 98 & 36.29 & $17^{\text {th }}$ \\
\hline C & Health related problem & & & \\
8. & High mortality rate & 121 & 44.81 & $15^{\text {th }}$ \\
9. & Unavailability of vaccines and medicines & 209 & 77.40 & $8^{\text {th }}$ \\
10. & High price of vaccines and medicines & 253 & 93.70 & $2^{\text {nd }}$ \\
11. & Lack of veterinary surgeon & 255 & 94.44 & $1^{\text {st }}$ \\
12. & Disease susceptibility & 131 & 48.51 & $14^{\text {th }}$ \\
\hline D & Other problems & & & \\
13. & Lack of artificial insemination facilities & 248 & 91.85 & $3^{\text {rd }}$ \\
14. & Lack of capital and loan facilities & 237 & 87.77 & $4^{\text {th }}$ \\
15. & Lack of marketing facilities & 189 & 70 & $11^{\text {th }}$ \\
16. & Lack of Govt. support & 227 & 84.07 & $6^{\text {th }}$ \\
17. & Lack of training facilities & 236 & 87.40 & $5^{\text {th }}$ \\
18. & Road accident (No. died in last year) & 15 & 5.5 & $18^{\text {th }}$ \\
\hline
\end{tabular}

\section{CONCLUSIONS}

The present study concluded that the major portion of the sheep farmers had small family, were illiterate, had no training on sheep farming, but had medium sheep farming experience with low extension media contact. Indigenous sheep of south-western coastal regions of Bangladesh were prolific in nature and their milk was only consumed by lambs. Though sheep farmers in the studied areas faced several problems, however, it was found prospective to the resource poor farmers for improving their income and livelihood. The farmers of the study area do not have an adequate educational qualification and competence for socio-economic up-lifting other than the experience and expertise for sheep farming, and thus sheep farming is of moderate to high prospect for improvement of their socioeconomic status. 


\section{Conflict of Interest}

There is none competing for the interests regarding the submitted manuscript, and the conducted research, except the authors mentioned in the list of authors.

\section{REFERENCES}

Ahamed, T., Hashem, M.A., Khan, M., Rahman, M.F. and Hossain, M.M. (2010). Factors related to small scale cattle fattening in rural areas of Bangladesh. Bangladesh Journal of Animal Science. 39 (1-2), pp. 116-124. https://doi.org/10.3329/bjas.v39i1-2.9684

Banerjee, R. (2008). Conservation and in situ development of a prolific indigenous sheep in the Sundarban and Sagar Island. PhD Thesis, University of Calcutta, Koltata, West Bengal, India.

Begum, M.A.A., Hossain, M.M., Khan, M., Rahman, M.M. and Rahman, S.M.E. (2007). Cattle fattening practices of selected farmers in Panchagarh district. Bangladesh Journal of Animal Science. 36 (1-2), pp. 62-72.

Bhuiyan, A.K.F.H. (2006). Livestock Genetic Resources in Bangladesh: Preservation and Management. International Conference on Livestock Services, Chinese Academy of Agricultural Science (CAAS), Beijing, China.

DLS (Department of Livestock Services). (2015). General information related to livestock. Annually Fisheries and Livestock Bulletin, published by Fisheries and Livestock Information Office, Khamarbari, Farmgate, Dhaka, Bangladesh. https://doi.org/10.4172/2332-2608.1000156

DLS (Department of Livestock Services). (2017). General information related to livestock. Annually Fisheries and Livestock Bulletin, published by Fisheries and Livestock Information Office, Khamarbari, Farmgate, Dhaka, Bangladesh. https://doi.org/10.4172/2332-2608.1000156

Ensiminger, M.E. (2002). Sheep and Goat Science. 6th ed. Interstate Publishers Inc., U.S.A. p. 82.

Hassan, M.R. and Talukder, M.A.I. (2011). Comparative performance of different regional native sheep in Bangladesh. The Bangladesh Veterinarian. 28 (2), pp. 85 - 94. https://doi.org/10.3329/ bvet.v28i2.10692

Hossain, M.D. (2013). Present status of organic beef cattle production in Shahjadpur upazila of Sirajgong district. MS thesis, Department of Animal Science, Faculty of Animal Husbandry, Bangladesh Agricultural University, Mymensingh. https://doi.org/10.3329/bjas.v45i1.27484

Hossain, M.D., Hossain, M.M., Hashem, M.A. and Bhuiyan, K.J. (2016). Oragnic beef cattle production pattern at Shahjadpur upazilla of Sirajgonj district in Bangladesh. Bangladesh Journal of Animal Science. 45(1), pp. 25-30.

Hossain, M.S., Hossain, M.M., Hashem, M.A. and Ali, R.N. (1996). Transfer of feeding technology to promote cattle production of village level. Bangladesh Journal of Animal Science. 25 (1-2), pp. 51-56.

Hossen, M.J., Hossain, M.S., Abedin, M.J., Karim, M.R. and Rume, F.I. (2008). Animal production strategies in southern region of Bangladesh. The Agriculturists. 6(1\&2), pp. 77-83. https://doi. org/10.3329/agric.v6i1.5217

Husain, S.S. and Amin, M.R. (2003): Genetic resource conservation and utilization: participatory maintenance of animal genetics resource at rural level in Bangladesh. Paper presented Genetic Resource Conservation, Bangladesh Livestock Research Institute, Savar, Dhaka, Bangladesh. https://doi.org/10.3329/jbau.v8i1.6407 
Islam, M.S., Islam, S.S., Islam, M.M. and Billah, M.M. (2019). Exploring women participation in small-scale dairy farming: A case of Paikgachha upazila, Khulna, Bangladesh. Asian Journal of Research in Animal and Veterinary Sciences. 3(4), pp. 1-13.

Kamal, M.M., Mondal, S.K., Islam, S.S. and Islam, M.S. (2012). Present status of goat rearing in three selected upazilas of Khulna district. The Journal of Rural Development. 37 (2), pp. 43-62.

Kishore, K., Gour, D., Rawat, P.S. and Malik, R.C. (1982). Note on some reproductive traits in three quarter bred strain of sheep. Indian Journal of Animal Science. 52, pp. 1108-1110.

Nimbkar, C., Ghalsasi, P.M., Walkden-Brown, S.W. and Kahn, L.P. (2002). Breeding program for the genetic improvement of Deccani sheep of Maharashtra, India. $7^{\text {th }}$ World Congress of Genetics Applied to Livestock Production, Montpellier, France. August 19-23.

Rahman, Z., Hossain, M.M. and Hashem, M.A. (2012). Cattle fattening program in Dinajpur district of Bangladesh. Progressive Agriculture. 23 (1-2), pp. 1-13.

Sarker, A.K., Amin, M.R., Hossain, M.A., Ali, M.S. and Hashem, M.A. (2017). Present status of organic sheep production in Ramgoti upazila of Lakshmipur district. Journal of Environmental Science \& Natural Resources. 10(2), pp. 95-103. https://doi.org/10.3329/jesnr.v10i2.39018

Sharma, P.K., Raha, S.K., and Jorgensen, H. (2014). An economic analysis of beef cattle fattening in selected areas of Pabna and Sirajgonj district. Journal of Bangladesh Agricultural University. 12(1), pp. 127-134. https://doi.org/10.3329/jbau.v12i1.21402

Sultana, N., Hossain, S.M.J., Chowdhury, S.A., Hassan, M.R. and Ershaduzzaman, M. (2010). Effects of age on intake, growth, nutrient utilization and carcass characteristics of castrated native sheep. The Bangladesh Veterinarian. 27, pp. 62-73. https://doi.org/10.3329/bvet.v27i2.7556

Zinea, T.I., Ahmed, M.B., Islam, S.S. and Islam, M.M. (2019). Consumers' awareness regarding the effect of antibiotic used in animal feed on human health. Asian Journal of Research in Animal and Veterinary Sciences. 4(1), pp. 1-11. 